\title{
DESAIN IMPLEMENTASI ANDON UNTUK PRODUCTION MONITORING SYSTEM BERBASIS INTERNET OF THING
}

Page | 89

\author{
Aris Budiyarto ${ }^{1}$, Gun Gun Maulana ${ }^{2}$, Ridwan $^{3}$, Fakhri Dzulfikar ${ }^{4}$
}

\author{
${ }^{1234}$ Jurusan Teknik Otomasi Manufaktur dan Mekatronika, \\ Politeknik Manufaktur Bandung Jl. Kanyakan 21, Bandung \\ ${ }^{1}$ Aris_b@polman-bandung.ac.id, ${ }^{2}$ gungun@polman-bandung.ac.id, ${ }^{3}$ ridwan@polman-bandung.ac.id, \\ ${ }^{4}$ fakhri@gmail.com
}

\begin{abstract}
Abstrak--Setiap produksi memerlukan sebuah sistem monitoring, sehingga efisiensi dan produktivitas yang diinginkan dapat tercapai dan dipantau secara real time. Sistem ini dibutuhkan dalam jenis produksi mesin press yang terutama dipengaruhi oleh produksi yang berbasis lead time. Proses monitoring adalah salah satu faktor yang mempengaruhi waktu produksi dan pabrikasi. Secara konvensional, sistem monitoring dilakukan secara manual oleh operator pada selembar kertas. Metode ini cenderung menciptakan error dan waktu yang cukup lama. Tulisan ini bertujuan untuk mengatasi masalah yang terjadi dengan menciptakan sistem yang mampu merekam dan memonitoring mesin secara otomatis. Solusi yang dibuat dengan memanfaatkan sensor limit switch, infrared, pressure transmitter dan jaringan Wi-Fi berbasis Web Interface yang terhubung dengan firebase real time database. Dilengkapi dengan PID control menggunakan metode Ziegler Nichols 1 untuk menstabilkan tekanan angin pada sistem. Perangkat monitoring dapat diakses pada PC, laptop, smartphone, yang terhubung dengan internet, dilengkapi dengan level pengguna operator, management, atau engineer sehingga dapat digunakan dengan mudah. Semua data produksi setiap mesin press dikumpulkan pada basis data. Data akan diolah sistem menghasilkan nilai OEE mesin. Semua data akan ditampilkan pada Web Interface secara realtime. Output sistem adalah actual produksi, nilai OEE dan kontrol tekanan angin. Hasil pengujian menunjukkan sistem berjalan dengan baik, dengan waktu delay 2 s dan akurasi data $\pm 0.2 \%$.
\end{abstract}

Kata kunci-- Production monitoring system, Web interface, OEE, basis data, firebase realtime database

Abstract--_Each production requires a system monitoring, so efficiency that the desired and productivity can be achieved and monitored in real time. This system is needed in the type of press machine production which is mainly influenced by based production lead time. The monitoring process is one of the factors that influences the time of production and manufacturing. Conventionally, the system is monitoring carried out manually by the operator on a piece of paper. This method tends to create errors and quite a long time. This paper aims to overcome the problems that occur by creating a system that is able to record and monitor the machine automatically. The solution is made by utilizing a sensor limit switch, infrared, pressure transmitter and Wi-Fi network based on Web Interface that is connected to the Firebase real time database. Equipped with PID control using the Ziegler Nichols 1 method to stabilize wind pressure on the system. Monitoring devices can be accessed on PCs, laptops, smartphones, connected to the internet, equipped with user-level operators, management, or engineers so that they can be used easily. All production data for each press is collected in a database. The data will be processed by the system to produce a value OEE machine. All data will be displayed on the Web Interface in real-time. The system output is the actual production, value $O E E$ and wind pressure control. The test results show the system is running well, with 2 s delay time and data accuracy of $\pm 0.2 \%$.

Keywords-- Production monitoring system, Web interface, OEE, basis data, firebase realtime database

\section{PENDAHULUAN}

Saat ini proses monitoring industri di Indonesia masih dilakukan secara manual dimana informasi didapatkan dari operator yang mengecek dan mengupdate kondisi terbaru pada mesin [2]. Informasi yang diperoleh secara manual tentu tidak reliable karena sering terjadi kesalahan pada operator, yang tentu bisa berdampak pada sistem produksi dan dan bisa merugikan perusahaan, selain itu sistem monitoring secara manual tidak efektif dan tidak efisien karena membutuhkan waktu yang cukup lama untuk memperbarui informasi [2]. Data produksi yang dikumpulkan pada saat ini masih banyak kesalahan karena intervensi manusia atau sistem pemantauan 
produksi yang tidak semestinya. Faktor manusia lebih banyak terjadi pada kasus ini. Seperti saat pemadaman unschedule terjadi, maka waktu dihabiskan untuk memecahkan masalah tersebut, sehingga hal ini dapat mengganggu proses produksi di perusahaan [3].

Hal ini membuat production monitoring system menjadi sangat penting berfungsi merealisasikan otomasi industri dengan tingkat efisiensi yang tinggi [4] sehingga kegiatan perawatan dan pemantauan tidak membutuhkan biaya mahal dan rumit untuk mendapatkan data yang dapat diandalkan setiap waktu [5]. Umumnya informasi yang perlu dipantau pada industri adalah tipe part yang dibuat, jumlah part yang telah diproduksi, dan life time mesin [6] dari informasi yang didapat dapat dilakukan perhitungan untuk mengetahui Availability, Performance, Quality, dan Overall Equipment Effectiveness [7]. Saat ini production monitoring system yang ada [7] telah berhasil membuat sebuah sistem monitoring dengan penggunaan raspberry pi dan web interface sebagai input otomatis pada perhitungan actual produksi pada sebuah mesin bubut di Estonia. Selain itu untuk sistem PMS yang telah dibuat di Indonesia [8] merupakan sistem PMS yang terpasang pada sebuah mesin bubut menggunakan raspberry $\mathrm{Pi}$ dan HMI mesin sebagai interface sistem PMS, sistem ini berfungsi hanya untuk menghitung waktu produksi mesin. Pada sistem production monitoring system ini dapat mengontrol penggunaan motor pada mesin bubut dengan penggunaan hall effect sensor. Dari kedua sistem tersebut masih memiliki kelemahan pada user friendly, penggunaan database, sistem yang belum reliable/mobile dan optimalisasi interface sistem PMS. Selain itu pada kedua sistem tersebut tidak terdapat proses perhitungan otomatis nilai OEE mesin yang terdiri dari Availability, Performance, Quality dan OEE mesin.

Production Monitoring System berbasis Internet Of Thing yang dirancang untuk mesin press memungkinkan perolehan data dari mesin press dengan tenaga pneumatik. Sistem ini berkaitan dengan jumlah dan tipe part yang dibuat, air pressure control, life time part, cycle time, dan jumlah actual production mesin yang dihubungkan dengan internet[9] dengan menggunakan cloud realtime database pada firebase sebagai penyimpanan data[10] dan diolah untuk menghasilkan nilai OEE mesin secara otomatis dan report yang berkala[11] pada web sebagai user interface [12] dari data yang diterima sehingga dapat diakses pada LED TV, smartphone, personal computer, laptop yang terhubung dengan internet. Membuat user dapat mengakses dimana saja dan kapan saja sehingga permasalahan dan kondisi mesin dapat dipantau secara realtime dan data yang diterima akan disimpan di web sebagai hasil produksi mesin press [13]. Dengan adanya sistem ini kesalahan dapat terdeteksi sedini mungkin sehingga akan mengurangi waktu yang terbuang dan meningkatkan performa mesin secara keseluruhan dan mengurangi risiko kritis mesin [14]. Sehingga dengan Production
Monitoring System berbasis Internet of Thing pada mesin press pneumatik ini diharapkan sistem produksi dan kontrol tekanan angin mesin akan menjadi lebih efektif, efisien, dan mobil

\section{METODE PENELITIAN}

Tahapan yang dilakukan pada penelitian ini merunut pada VDI 2206 yang telah digambarkan secara umum. Adapun Perincian alur tahapan penelitian dijelaskan pada gambar 1 .
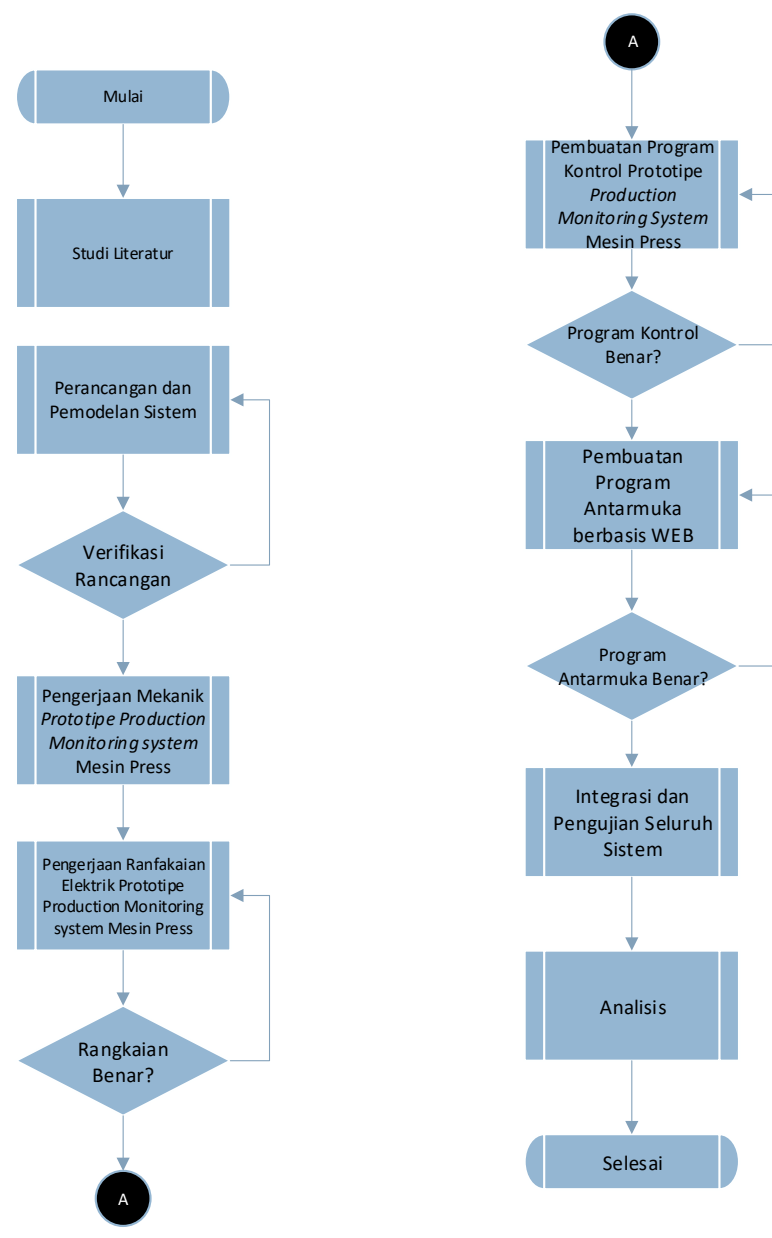

Gbr. 1 Tahapan Penelitian

\section{A. Studi Literatur}

Pada tahapan ini dilakukan pengumpulan materimateri dari berbagai sumber yang berhubungan dengan sistem yang akan dibuat. Materi-materi tersebut dipelajari dan dijadikan sebagai acuan dasar pembuatan sistem.

\section{B. Perancangan dan Pemodelan Sistem}

Pembuatan rancangan sistem meliputi beberapa aspek penting diantaranya. Domain informatik/ kontrol, domain elektrik dan domain mekanik menjadi bagian sistem yang dibuat. Secara garis besar, langkah 
pengaplikasian sesuai dengan standar perancangan VDI 2206[18]. Perancangan sistem prototipe production monitoring system mesin press berbasis IoT meliputi perancangan mekanik, perancangan elektrik, dan juga perancangan informatik serta pemodelan Page| 91 algoritma pemrograman. Tahap ini dimaksudkan agar memudahkan dalam pelaksanaan penelitian, dan juga mengurangi tingkat kesalahan saat melaksanakan penelitian. Gambar 3 menunjukkan gambaran umum production monitoring system yang akan dibuat meliputi control, mekanik dan informatik sistem.

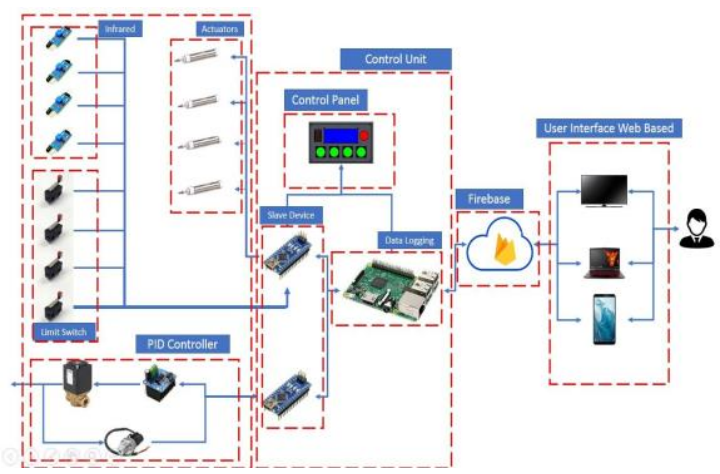

Gbr. 2 Gambaran umum sistem

\section{Pengerjaan mekanik prototipe PMS}

Setelah perancangan selesai kemudian pembuatan mekanik untuk prototipe mesin press. Tahap ini meliputi penyediaan bahan-bahan dan komponenkomponen yang akan digunakan dalam penelitian. Kemudian, bahan-bahan dan komponen komponen tersebut dibangun menjadi mekanik prototipe production monitoring system mesin press. Setelah menyelesaikan pengerjaan mekanik untuk prototipe mesin. Gambar 3 menunjukkan design mekanik prototipe mesin press tampak depan. Terdiri dari 3 bagian utama yaitu panel control, prototipe mesin press, dan meja rangkaian elektrik pada bagian bawah.

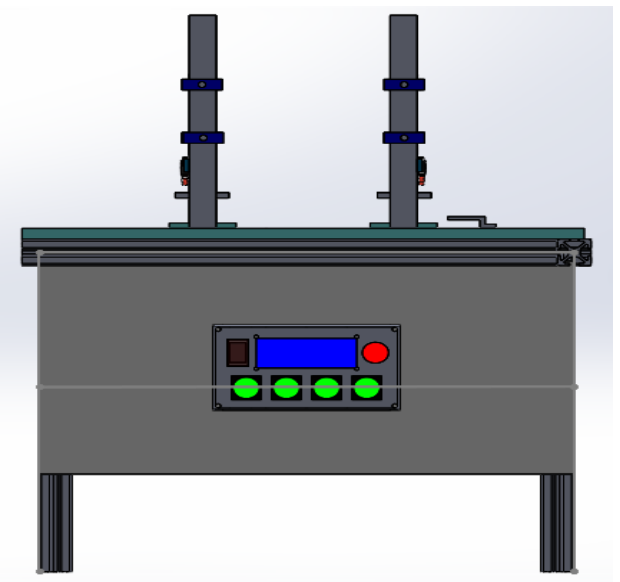

Gbr. 3 Design Mekanik tampak depan

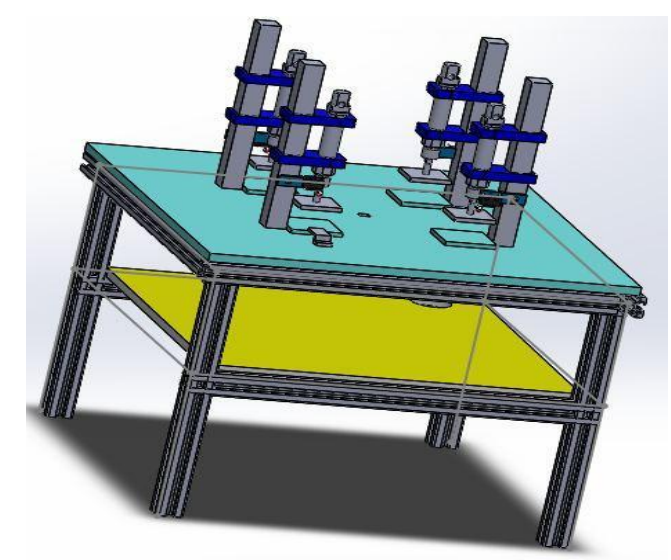

Gbr. 4 Design mekanik tampak samping

Dalam Tahapan mekanik meliputi juga penyediaan bahan-bahan dan komponen pneumatic yang akan digunakan. Diantaranya silinder solenoid valve dan proportional valve. Pada Gambar 4 menunjukkan 4 silinder pneumatic sebagai simulasi dari 4 mesin press yang nantinya akan di monitoring pada production monitoring system berbasis IoT.

\section{Pengerjaan rangkaian elektrik PMS}

Setelah pembuatan mekanik sistem production monitoring system, selanjutnya adalah perangkaian rangkaian listrik dari sistem sesuai dengan gambar rangkaian listrik yang sudah dibuat pada tahap perancangan sistem pada gambaran umum sistem yang ditunjukkan oleh gambar 2. Rangkaian elektrik sendiri akan terpasang dibawah prototipe mesin press, ditunjukkan oleh gambar 4 meja yang berwarna kuning merupakan meja rangkaian elektrik pada sistem PMS. Rangkaian elektrik terdiri dari sensor limit switch, sensor ir infrared, sensor pressure transmitter, sementara untuk output terdiri dari 8 buah relay, 5 buah push button control, proportional valve, dan 4 buah solenoid valve 5/2 double acting yang digunakan untuk mengontrol silinder. Setiap input dan output pada sistem dikontrol oleh 2 buah Arduino nano yang berfungsi sebagai slave device dan 1 buah Raspberry Pi 3 yang digunakan sebagai master device untuk data logging proses IoT pada sistem yang akan terhubung secara realtime dengan firebase database

\section{E. Pembuatan program kontrol PMS}

Pada tahap ini dilakukan pemrograman pengendali prototipe PMS. Pemrograman dilakukan sesuai dengan algoritma yang sudah dirancang pada tahap perancangan sistem prototipe PMS. Setelah program selesai dibuat, dilakukan uji coba program tersebut sekaligus menganalisanya. Program control yang dibuat pada sistem ini meliputi control unit PID, control silinder dan saluran pneumatic, dan data logging untuk sensor limit switch untuk actual production dan infrared sebagai sensor benda kerja. 
Page $\mid 92$

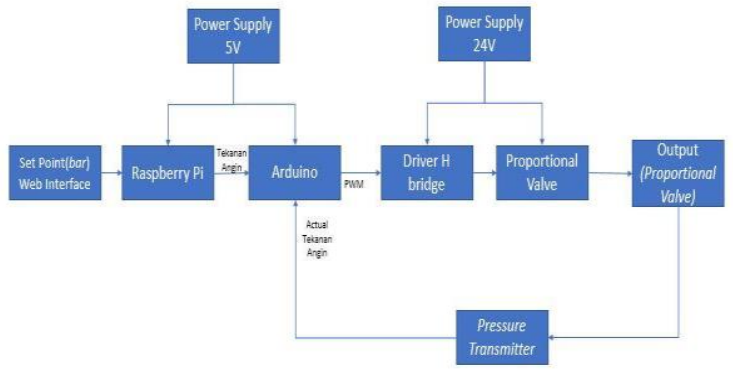

Gbr. 5 PID controller

PID digunakan untuk menstabilkan tekanan angin yang masuk pada sistem PMS. Pada gambar 2 menunjukkan kontrol PID pada sistem production monitoring system. Apabila berhasil maka lanjut ke tahap pembuatan program antarmuka untuk pemantauan sistem prototipe bendung, apabila tidak maka kembali lagi ke tahap pembuatan program pengendali.

\section{F. Pembuatan program antarmuka berbasis WEB}

Pada tahap ini dilakukan pemrograman antarmuka untuk pemantauan sistem production monitoring system pada prototipe mesin press. Pemrograman dilakukan sesuai dengan algoritma yang sudah dirancang pada tahap perancangan.Gambar 5 menunjukkan proses diagram alir sistem yang akan dilakukan.

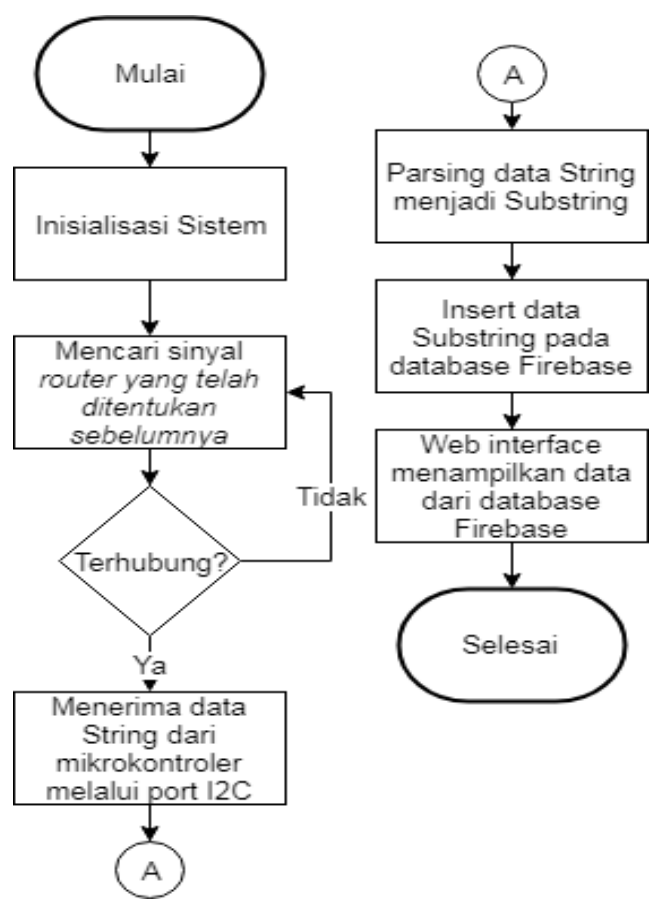

Gbr. 6 Alur pengiriman data Web Interface

Gambar 6 menunjukkan proses pengiriman data menuju Web interface. Tahap awal program pengiriman data kepada web interface adalah inisialisasi sistem. Kemudian, dilanjutkan dengan menghubungkan Raspberry Pi dengan jaringan wifi di sekitarnya. Raspberry Pi memerlukan data SSID serta Password dari jaringan wi-fi yang digunakan untuk dapat terhubung. Ketika Raspberry Pi telah terhubung dengan jaringan wi-fi, tahap selanjutnya adalah membaca data String dari mikrokontroler slave. Data ini kemudian akan di parsing menjadi beberapa bagian Substring agar dapat dikirimkan kepada database Firebase. Raspberry Pi akan mengirim data substring setiap 3 detik sekali. Antarmuka web terhubung langsung dengan database Firebase, sehingga dapat langsung menampilkan data.

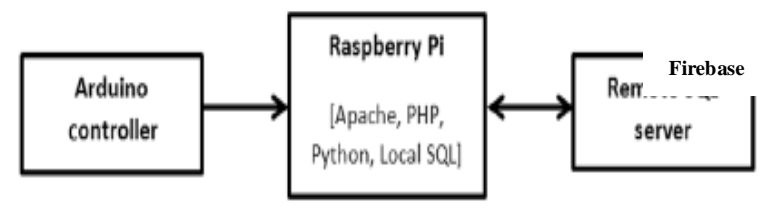

Gbr. 7 Data logging proses

Gambar 7 menunjukkan proses data logging pada production monitoring system. Terdiri dari 3 bagian utama Arduino sebagai controller terbagi menjadi 2 bagian untuk control silinder pneumatic dan untuk control PID pada sistem. Semua data yang diterima pada Arduino akan langsung dikirimkan pada Raspberry pi 3 sebagai data logger pada sistem. Setelah semua data yang berupa string diterima akan langsung dikirimkan ke firebase realtime database yang nantinya akan masuk pada WEB sebagai interface yang bekerja secara realtime.

\section{G. Integrasi dan Pengujian Seluruh Sistem}

Pada tahapan ini dilakukan penggabungan sistem secara keseluruhan, baik sistem mekanik, elektrik, dan juga program kendali serta antarmuka menjadi sebuah prototipe. Kemudian dilakukan pengujian sistem yang sudah dirakit menjadi sebuah prototipe. Hasil yang diharapkan dari pengujian ini adalah keakuratan dan ketangguhan sistem dalam memonitoring nilai tekanan angin, lifetime, tipe part jumlah actual production mesin press dan OEE dari setiap mesin yang dapat dipantau secara real time tanpa terbatas tempat dimana saja, sehingga data dapat digunakan oleh management untuk preventive mesin atau dapat memberikan keputusan secara cepat dilihat dari OEE(Overall Equipment Effectiveness) yang didapat oleh sebuah mesin apabila terjadi suatu masalah dapat dipantau menggunakan handphone, LED TV, Laptop, Smartphone yang terhubung ke internet.

\section{H. Analisis}

Pada tahapan ini hasil dari pengujian sistem akan dianalisis dan disimpulkan, kemudian disusun menjadi sebuah laporan yang sistematis.

Perhitungan Nilai efisiensi mesin Nilai OEE mesin didapatkan dari beberapa parameter mesin seperti 


\section{Page | 93 perhitungan Availability.}

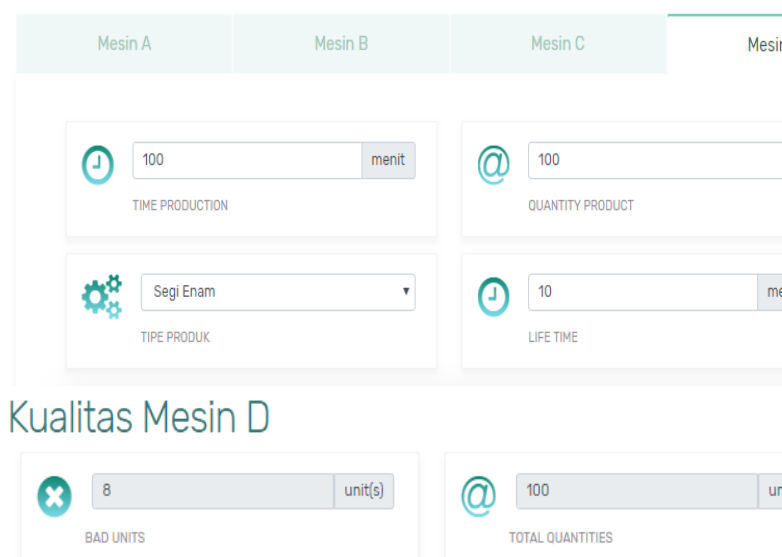

Gbr. 8 Parameter mesin perhitungan nilai efisiensi mesin

TABEL I

TABEL PERHITUNGAN NILAI OEE MESIN

\begin{tabular}{|c|c|c|}
\hline No & Parameter & $\begin{array}{c}\text { Nilai } \\
\text { Efisiensi } \\
\text { Mesin }\end{array}$ \\
\hline 1 & $\begin{array}{c}\text { Time } \\
\text { Production/ActualLifeTime }\end{array}$ & Availability \\
\hline 2 & $\begin{array}{c}\text { (CycleTime mesin } x \text { Actual } \\
\text { produksi)/Time Production }\end{array}$ & Performance \\
\hline 3 & $\begin{array}{c}\text { Not Good Product/Total } \\
\text { Product }\end{array}$ & Quality \\
\hline 4 & $\begin{array}{c}\text { Availability } x \text { Performance } \\
x \text { Quality }\end{array}$ & OEE \\
\hline
\end{tabular}

\section{HASIL DAN PEMBAHASAN}

Rancangan sistem kontrol irigasi tetes pada gambar 3 telah diimplementasikan dengan membuat prototype sistem seperti yang terdapat pada gambar 9 .

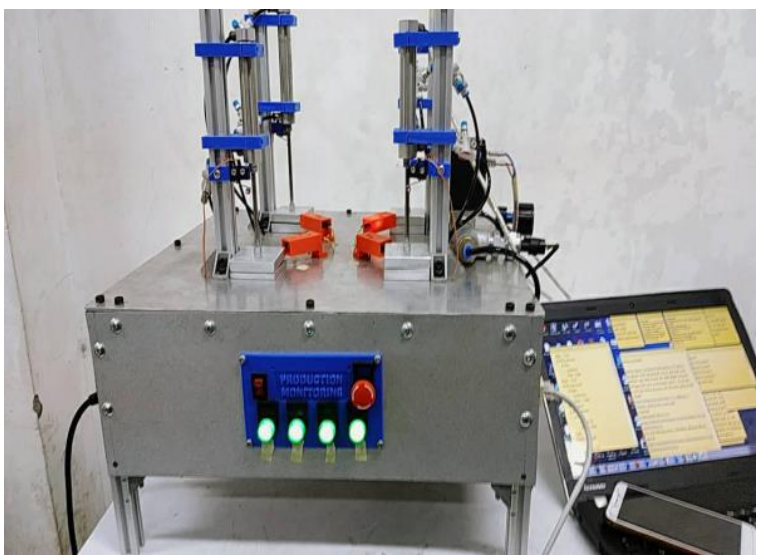

Gbr. 9 Prototipe sistem PMS

Implementasi sistem terdiri dari tiga bagian yaitu plant sistem disertai unit pemroses yang mendapatkan sumber internet dari wireless router, realtime database menggunakan firebase, dan firebase hosting pada bagian Web interface. Unit pemroses terbagi menjadi 2 yaitu unit control yang berbentuk meja yang terdiri dari 4 buah silinder yang merupakan prototipe dari 4 buah mesin press. Dipasang menggunakan profil aluminium dan filamen 3d printer sebagai joint, terhubung dengan sensor limit switch, pressure transmitter, infrared proportional valve dan solenoid valve. Dan unit elektrik yang terdiri dari panel control dan rangkaian elektrik sistem. Untuk menghubungkan sistem ke internet digunakan wireless router. Bagian kedua adalah realtime database menggunakan firebase untuk menyimpan data pembacaan sensor. Data base ini dapat diakses menggunakan WEB interface yang telah dibuat. $W E B$ interface sendiri dapat diakses melalui smartphone, laptop atau komputer yang terhubung dengan internet. Sistem melalui jaringan internet sehingga user dapat mengakses akuisisi data dari mana saja selama aplikasi WEB dan unit pemroses terkoneksi internet.

Setelah sistem berhasil diimplementasikan maka selanjutnya dilakukan pengujian terhadap sensor pressure transmitter dan limit switch. Pengujian bertujuan untuk mengetahui karakteristik sensor dan parameter yang diukur. Pengujian sensor pressure transmitter dilakukan dengan membandingkan hasil pengukuran sistem dan pembacaan pada pressure digital sedangkan pada sensor limit switch dilakukan pengujian terhadap respon time sensor hingga data diterima oleh WEB interface. Gambar 10 menunjukkan cara pengujian sensor pressure transmitter dan limit switch.

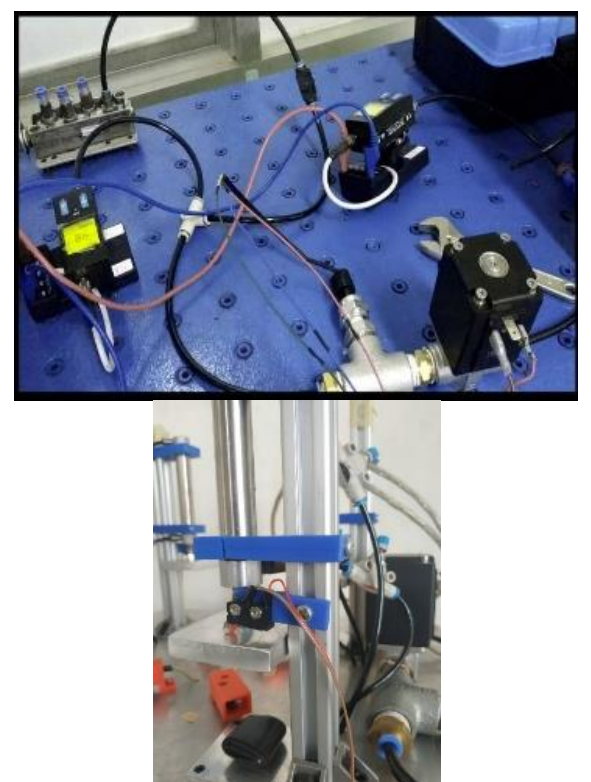

Gbr. 10 (a)Pengujian sensor pressure transmitter, (b)pengujian sensor limit switch

Pada pengujian sensor pressure transmitter dilakukan pengujian pembacaan sensor terhadap tekanan angin yang masuk dan terbaca oleh sensor. 
Pengujian ini sekaligus kalibrasi keakuratan sensor pressure transmitter terhadap tekanan angin yang masuk dengan membandingkan tekanan angin masuk yang dibaca oleh pressure bar digital dan tekanan angin yang terbaca oleh sensor.Tekanan angin yang diberikan dibatasi pada 5 bar. Seperti ditunjukkan oleh Tabel 1 yaitu perbandingan keakuratan sensor pressure transmitter dengan pressure digital yang dipasang paralel dengan sensor.

TABEL II

NILAI PEMBACAAN PRESSURE TRANSMITTER

\begin{tabular}{|c|c|l|c|c|}
\hline No & $\begin{array}{c}\text { Pressure } \\
\text { Transmitter }\end{array}$ & & $\begin{array}{c}\text { Pressure } \\
\text { Digital }\end{array}$ & $\begin{array}{c}\text { Err } \\
(\%)\end{array}$ \\
\hline 1 & 4.99 & & 5 & 0.2 \\
\hline 2 & 4.99 & & 5 & 0.2 \\
\hline 3 & 5.01 & & 5 & 0.199 \\
\hline 4 & 5 & & 5 & 0 \\
\hline 5 & 5.01 & & 5 & 0.199 \\
\hline 6 & 5.01 & & 5 & 0.199 \\
\hline 7 & 5 & & 5 & 0 \\
\hline 8 & 5 & & 5 & 0 \\
\hline 9 & 5 & & 5 & 0 \\
\hline 10 & 4.99 & & 5 & 0.2 \\
\hline 11 & 4.99 & & 5 & 0.2 \\
\hline 12 & 5 & & 5 & 0 \\
\hline 13 & 5 & & 5 & 0 \\
\hline 14 & 5.01 & & 5 & 0.9 \\
\hline 15 & 5 & & 5 & 0 \\
\hline
\end{tabular}

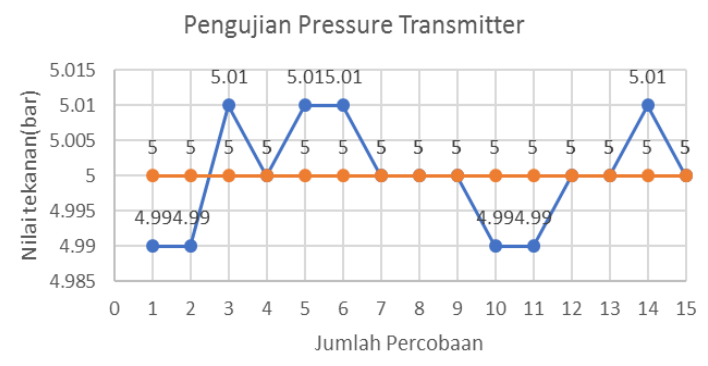

$\rightarrow$ Pressure Trasnmitter $\quad \rightarrow$-Pressure Digital

Gbr. 11 Hasil pengujian sensor

Pada Gambar 11 merupakan Grafik nilai antara pengukuran dan pembacaan sensor pressure transmitter. Dengan nilai awal tekanan masuk 5 bar, sensor membaca tekanan pada 4.99 bar ,5 bar, ataupun 5.01 bar. Pressure transmitter menunjukkan nilai pembacaan sensor tekanan angin. Sementara Pressure digital menunjukkan nilai pengukuran tekanan angin. Seperti pada Tabel 1 yang menjelaskan tentang nilai pembacaan sensor. Dalam gambar 10 dapat dilihat keakuratan nilai sensor $\pm 0.2 \%$ dalam 15 kali percobaan.

Pengujian yang dilakukan pada sensor ini meliputi dengan keceatan respon sensor, karena berkaitan dengan penggnaan sensor ini sebagai counter jumlah realtime prodksi pada sebuah mesin press. Sensor ini bekerja ketika mesin press selesai melakukan proses press dan dice kembali ke posisi 0 maka limit switch akan tertekan dan memberikan input pada slave device yang dikirimkan master device menjadi data logging yang akan langsung dikirimkan ke firebase database. Pengujian yang dilakukan berkaitan dengan proses pembacaan limit switch terhadap respon waktu pengiriman seperti pada Tabel II yang menjelaskan tentang kecepatan waktu pengiriman sesuai dengan limit switch yang tertekan terlebih dahulu.

TABEL III

RESPON WAKTU LIMIT SWITCH

\begin{tabular}{|c|c|c|c|c|c|}
\hline \multirow[b]{2}{*}{$\begin{array}{c}\mathbf{N} \\
\mathbf{0}\end{array}$} & \multirow[b]{2}{*}{$\begin{array}{c}\text { Nilai } \\
\text { Limit } \\
\text { Switc } \\
\text { h } \\
\end{array}$} & \multicolumn{4}{|c|}{ Respon Waktu (s) } \\
\hline & & $\begin{array}{c}\text { Limit } \\
\text { Switch } \\
1\end{array}$ & $\begin{array}{c}\text { Limit } \\
\text { Switch } \\
2\end{array}$ & $\begin{array}{c}\text { Limit } \\
\text { Switch } \\
3\end{array}$ & $\begin{array}{c}\text { Limit } \\
\text { Switch } \\
\mathbf{4}\end{array}$ \\
\hline 1 & 1 & 0.89 & 0.88 & 0.88 & 0.89 \\
\hline 2 & 1 & 0.88 & 0.86 & 0.86 & 0.88 \\
\hline 3 & 1 & 0.88 & 0.88 & 0.88 & 0.88 \\
\hline 4 & 1 & 0.87 & 0.89 & 0.89 & 0.87 \\
\hline 5 & 1 & 0.88 & 0.87 & 0.87 & 0.88 \\
\hline 6 & 1 & 0.88 & 0.86 & 0.86 & 0.88 \\
\hline 7 & 1 & 0.89 & 0.86 & 0.86 & 0.89 \\
\hline 8 & 1 & 0.89 & 0.86 & 0.86 & 0.89 \\
\hline 9 & 1 & 0.89 & 0.86 & 0.86 & 0.89 \\
\hline 10 & 1 & 0.88 & 0.87 & 0.87 & 0.88 \\
\hline 11 & 1 & 0.88 & 0.86 & 0.86 & 0.88 \\
\hline 12 & 1 & 0.88 & 0.86 & 0.86 & 0.88 \\
\hline 13 & 1 & 0.87 & 0.86 & 0.86 & 0.87 \\
\hline 14 & 1 & 0.88 & 0.87 & 0.87 & 0.88 \\
\hline 15 & 1 & 0.88 & 0.86 & 0.86 & 0.86 \\
\hline 16 & 1 & 0.88 & 0.86 & 0.86 & 0.86 \\
\hline 17 & 1 & 0.87 & 0.86 & 0.86 & 0.86 \\
\hline 18 & 1 & 0.87 & 0.87 & 0.87 & 0.87 \\
\hline 19 & 1 & 0.89 & 0.87 & 0.87 & 0.87 \\
\hline 20 & 1 & 0.89 & 0.87 & 0.87 & 0.87 \\
\hline $\mathrm{R}$ & Rata & 0.88 & 0.87 & 0.87 & 0.87 \\
\hline
\end{tabular}

\section{Respon Limit Switch}

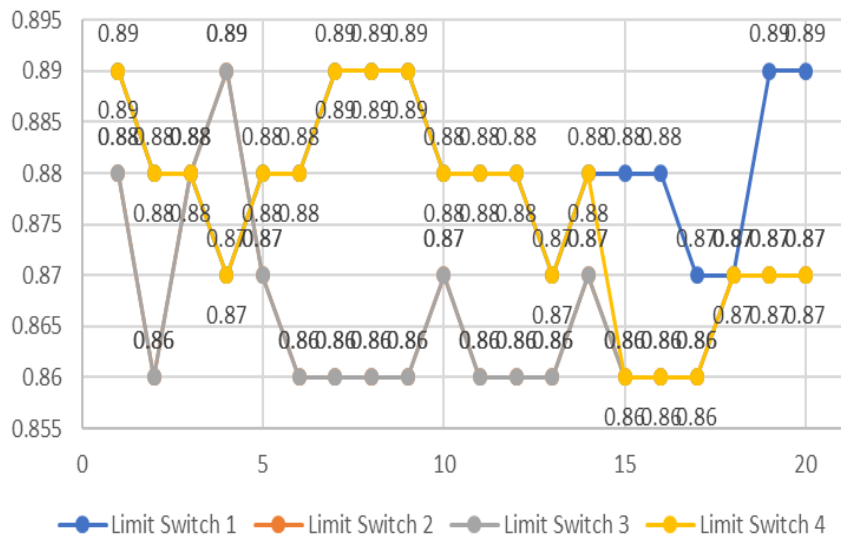

Gbr. 12 Respon Waktu Limit Switch 
Pada gambar 12 menunjukkan respon waktu yang didapat dari pembacaan sensor limit switch dalam satuan detik. Waktu tersebut didapat dengan cara menghitung respon off limit switch menjadi on pada WEB interface yang telah dibuat. Dari pengujian diatas didapatkan hasil bahwa respon waktu limit switch ratarata sebesar $0.87 \mathrm{~s}$.

Sistem PID yang dilakukan pada production monitoring system ini berkaitan dengan mempertahankan tekanan angin stabil pada tekanan yang sesuai dengan setpoint yang telah ditentukan sebelumnya pada web interface. Sehingga user dapat merubah nilai set point sesuai kebutuhan mesin. Sesuai dengan perancangan PID yang telah dilakukan pada sistem PID ini menggunakan metode tuning Ziegler Nichols dengan gambaran sistem close loop menggunakan proportional valve sebagai valve alat yang mengontrol tekanan angin masuk dan keluar pada sistem.

Pengujian kecepatan pengiriman data yang dilakukan dengan membandingkan penggunaan jaringan LTE dan HSDPA.Berikut hasil perbandingan kecepatan mengirim data menggunakan internet dengan koneksi High Speed Downlink Packet Access (HSDPA) dan dengan menggunakan koneksi Long Term Evolution.

TABEL IV

PENGUJIAN JARINGAN HSDPA

\begin{tabular}{|c|c|c|}
\hline No & Pengujian ke- & Respon waktu (s) \\
\hline 1 & 1 & 2.75 \\
\hline 2 & 2 & 2.57 \\
\hline 3 & 3 & 2.43 \\
\hline 4 & 4 & 2.40 \\
\hline 5 & 5 & 2.40 \\
\hline \multicolumn{2}{|c|}{ Rata-rata } & 2.51 \\
\hline
\end{tabular}

TABEL $V$

PENGUJIAN JARINGAN LTE

\begin{tabular}{|c|c|c|}
\hline No & Pengujian ke- & Respon waktu (s) \\
\hline 1 & 1 & 2.05 \\
\hline 2 & 2 & 2.05 \\
\hline 3 & 3 & 2.03 \\
\hline 4 & 4 & 2.03 \\
\hline 5 & 5 & 2.05 \\
\hline \multicolumn{2}{|c|}{ Rata-rata } & 2.04 \\
\hline
\end{tabular}

Dari pengujian yang dilakukan, dapat dilihat bahwa rata-rata waktu respon pada table IV dan Vyang dibutuhkan untuk mengeksekusi perintah yang diberikan pada koneksi HSDPA adalah 2.51 detik, sedangkan pada koneksi LTE adalah 2.04 detik. Hasil ini menunjukkan bahwa kecepatan untuk merespon pada koneksi LTE lebih baik dibandingkan dengan koneksi HSDPA. Namun, hasil tersebut dapat bervariasi yang diakibatkan oleh kekuatan penerimaan sinyal dari modem yang digunakan tersebut.

Pengujian sistem monitoring produksi mesin bertujuan untuk menguji keakuratan data yang diterima oleh sistem terhadap perhitungan nilai produksi secara otomatis. Pengujian ini membandingkan nilai perhitungan manual dengan perhitungan otomatis sistem. Dilakukan sebanyak 5 kali pengujian dengan kuantitas pengujian diatas 50 kali. Seperti ditunjukkan oleh gambar 13.

Produksi hari ini MESIN A

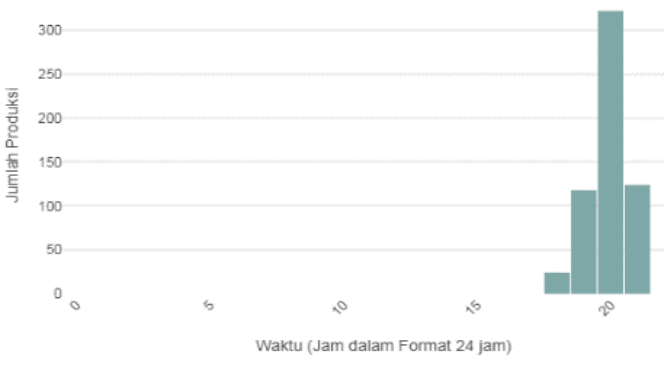

Gbr. 13 Respon Waktu Limit Switch

TABEL VI

PERBANDINGAN PERHITUNGAN MONITORING MANUAL DAN OTOMATIS

\begin{tabular}{|c|c|c|c|c|}
\hline No. & Waktu & $\begin{array}{c}\text { Perhitunga } \\
\text { n manual }\end{array}$ & $\begin{array}{c}\text { Perhitun } \\
\text { gan } \\
\text { Sistem }\end{array}$ & $\begin{array}{c}\text { Error } \\
\text { Perhitun } \\
\text { gan }\end{array}$ \\
\hline 1 & $\begin{array}{c}17.00- \\
18.00\end{array}$ & 20 & 20 & $0 \%$ \\
\hline 2 & $\begin{array}{c}18.00- \\
19.00\end{array}$ & 120 & 120 & $0 \%$ \\
\hline 3 & $\begin{array}{l}19.00- \\
20.00\end{array}$ & 310 & 320 & $3.12 \%$ \\
\hline 4 & $\begin{array}{c}20.00- \\
21.00\end{array}$ & 120 & 122 & $1.64 \%$ \\
\hline \multicolumn{2}{|c|}{ Jumlah Total } & 570 & 582 & $2.06 \%$ \\
\hline
\end{tabular}

Pada table VI Proses pengujian pada mesin A dilakukan dengan membandingkan perhitungan produksi secara manual dan perhitungan produksi secara otomatis oleh sistem berdasarkan pembacaan dari limit switch. Pengujian pada mesin A dilakukan 4 kali pengujian dengan jumlah produksi yang berbeda pada tiap jam. Error yang dihasilkan oleh sistem pada proses pembacaan produksi mesin A paling besar terjadi pada uji coba pukul 19.00-20.00 sekitar 3.12\% dengan total produksi pada jam tersebut sekitar 310 produk yang dibaca. Untuk jumlah total yang diproduksi oleh mesin A selama 4 jam yaitu sebanyak 570 unit, terjadi error pembacaan sekitar $2.06 \%$.

Pengujian Nilai efisiensi mesin. Pada pengujian ini dilakukan pengujian dengan membandingkan hasil perhitungan nilai OEE mesin secara manual meliputi Availability, Performance, Quality, dan OEE dengan hasil perhitungan pada sistem PMS berbasis IoT yang telah dibuat.Pengujian dilakukan pada tanggal 19 Agustus 2019.

Pada gambar 14 menunjukkan hasil aktual produksi mesin, dimana hanya mesin $\mathrm{D}$ yang beroperasi sementaranya mesin $\mathrm{A}$, mesin $\mathrm{B}$, mesin $\mathrm{C}$ dalam 
keadaan stand by terbukti dengan munculnya angka Availability yang berasal dari Actual Time ketika kondisi mesin Running. Pada gambar 4.18 menunjukkan nilai OEE mesin yang dihasilkan dari perhitungan pada sistem secara otomatis.

Page | 96

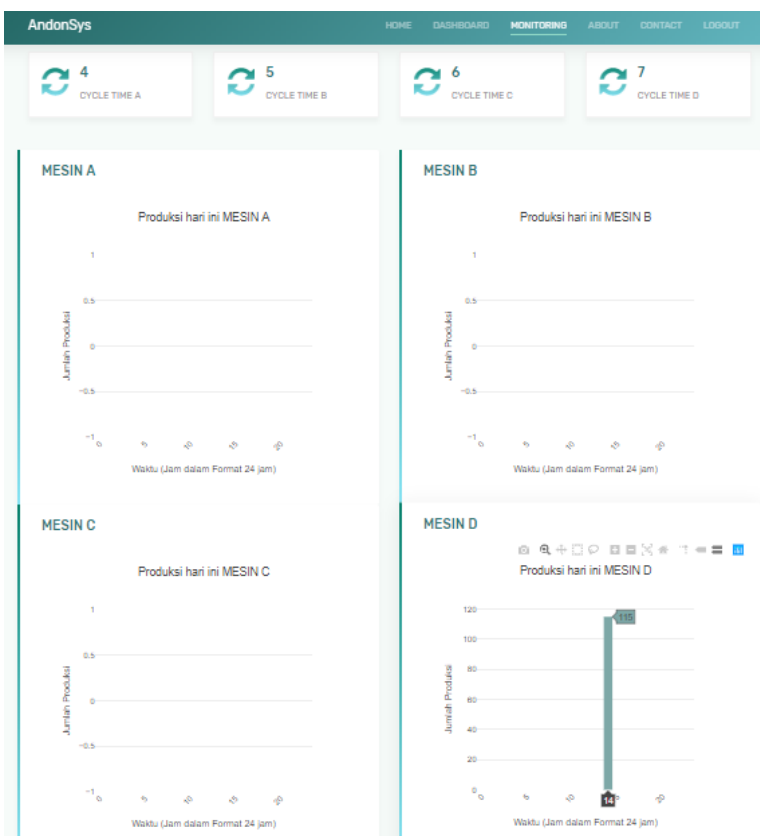

Gbr. 14 Hasil Actual Produksi dan cycle time mesin

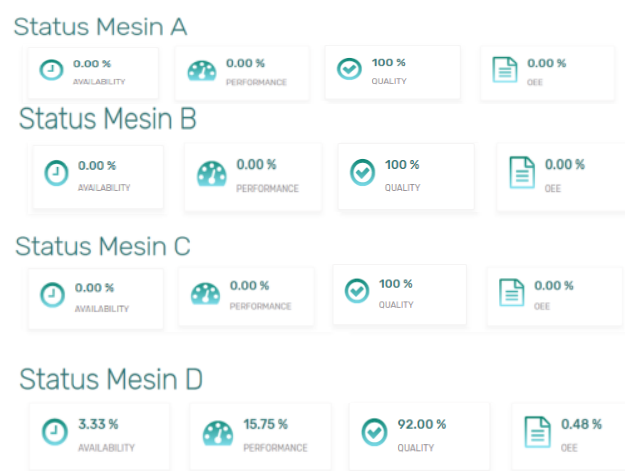

Gbr. 15 Hasil Perhitungan Otomatis Nilai Efisiensi Mesin

Pengujian dilakukan pada setiap mesin yaitu mesin $\mathrm{A}$, mesin $\mathrm{B}$, mesin $\mathrm{C}$, mesin $\mathrm{D}$ dengan pergerakan mesin yang konstan berdasarkan cycle time. Pada pengujian nilai efisiensi mesin, mesin D yang hanya berproduksi dilihat hasil dari grafik produksi yang berhasil dihitung oleh sistem dan diolah pada web interface. Tabel 7, tabel 8, tabel 9, tabel 10 menunjukkan perbandingan nilai OEE yang dihitung secara manual dan nilai OEE hasil perhitungan sistem pada gambar 15 .
TABEL VII

PERHITUNGAN MANUAL NILAI EFISIENSI MESIN A

\begin{tabular}{|l|l|l|l|l|l|l|}
\hline N & Wakt & Prod & \multicolumn{3}{|l|}{ Perhitungan (\%) } \\
\cline { 4 - 7 } o. & $\mathbf{u}$ & uksi & $\begin{array}{l}\text { Availi } \\
\text { bility }\end{array}$ & $\begin{array}{l}\text { Perfor } \\
\text { mance }\end{array}$ & $\begin{array}{l}\text { Qua } \\
\text { lity }\end{array}$ & $\begin{array}{l}\text { O } \\
\text { E } \\
\text { E }\end{array}$ \\
\hline 1 & $\begin{array}{l}20 / 08 / \\
2019\end{array}$ & 0 & 0 & 0 & 100 & 0 \\
\hline
\end{tabular}

TABEL VIII

PERHITUNGAN MANUAL NILAI EFISIENSI MESIN B

\begin{tabular}{|l|l|l|l|l|l|l|}
\hline N & Wakt & Prod & \multicolumn{3}{|l|}{ Perhitungan (\%) } \\
\cline { 4 - 7 } o. & $\mathbf{u}$ & uksi & $\begin{array}{l}\text { Availi } \\
\text { bility }\end{array}$ & $\begin{array}{l}\text { Perfor } \\
\text { mance }\end{array}$ & $\begin{array}{l}\text { Qua } \\
\text { lity }\end{array}$ & $\begin{array}{l}\text { O } \\
\text { E } \\
\text { E }\end{array}$ \\
\hline 1 & $\begin{array}{l}20 / 08 / \\
2019\end{array}$ & 0 & 0 & 0 & 100 & 0 \\
\hline
\end{tabular}

TABEL IX

PERHITUNGAN MANUAL NILAI EFISIENSI MESIN C

\begin{tabular}{|l|l|l|l|l|l|l|}
\hline N & Wakt & Prod & \multicolumn{4}{|l|}{ Perhitungan (\%) } \\
\cline { 4 - 7 } o. & $\mathbf{u}$ & uksi & $\begin{array}{l}\text { Availi } \\
\text { bility }\end{array}$ & $\begin{array}{l}\text { Perfor } \\
\text { mance }\end{array}$ & $\begin{array}{l}\text { Qua } \\
\text { lity }\end{array}$ & $\begin{array}{l}\text { O } \\
\text { E } \\
\text { E }\end{array}$ \\
\hline 1 & $\begin{array}{l}20 / 08 / \\
2019\end{array}$ & 0 & 0 & 0 & 100 & 0 \\
\hline
\end{tabular}

TABEL X

PERHITUNGAN MANUAL NILAI EFISIENSI MESIN D

\begin{tabular}{|l|l|l|l|l|l|l|}
\hline N & Wakt & Prod & \multicolumn{4}{|l|}{ Perhitungan (\%) } \\
\cline { 4 - 7 } o. & $\mathbf{u}$ & uksi & $\begin{array}{l}\text { Availi } \\
\text { bility }\end{array}$ & $\begin{array}{l}\text { Perfor } \\
\text { mance }\end{array}$ & $\begin{array}{l}\text { Qua } \\
\text { lity }\end{array}$ & $\begin{array}{l}\text { O } \\
\text { E } \\
\text { E }\end{array}$ \\
\hline 1 & $20 / 08 /$ & 135 & 3.33 & 15.75 & $\begin{array}{l}92.0 \\
0\end{array}$ & $\begin{array}{l}0.4 \\
8\end{array}$ \\
\hline
\end{tabular}

Pada Tabel VII, IX,dan X pengujian nilai efisiensi mesin. Perhitungan secara manual nilai efisiensi mesin sama dengan perhitungan otomatis yang dilakukan oleh sistem PMS yang telah dibuat. Terbukti dengan nilai yang sama pada Tabel 10 dan gambar 15 khususnya pada mesin D. Sehingga pada percobaan ini dapat dibuktikan bahwa sistem telah mampu dan dapat menghitung nilai efisiensi mesin secara akurat dan sesuai dengan perhitungan yang akurat.

Nilai efisiensi mesin pada tabel 10 didapat dari perhitungan rumus efisiensi mesin secara manual sesuai dengan rumus berikut:

Availability $=\frac{333}{100}=3.33 \%$

Performance $=\frac{7 \times 135}{100 \times 60}=15.75 \%$

(2)

Quality $=\frac{92}{100}=92 \%$ 


\author{
$\mathrm{OEE}=3.33 \times 15.75 \times 920 \mathrm{EE}=3.33 \times 15.75 \times 92=$ \\ 0.48
}

Perhitungan Performance mesin D merupakan perhitungan cycle time mesin dikali dengan aktual produksi dibagi dengan lama nya produksi yang

Page|97 direncanakan semua parameter tersebut didapat dari gambar 4.18 untuk waktu perencanaan produksi dan parameter aktual produksi didapat pada gambar 4.19 sesuai dengan grafik mesin D.

Perhitungan Quality produk pada setiap mesin A, mesin $\mathrm{B}$, mesin $\mathrm{C}$ merupakan kualitas produksi sebelum terjadinya reject atau NG Product. Pada mesin Dinilai Quality berkurang menjadi 92\% karena terdapat 8 buah NG produk seperti yang ditampilkan pada gambar 15 status mesin D.

Untuk perhitungan nilai OEE merupakan perkalian antara Availability $x$ Performance $x$ Quality yang didapat oleh mesin. Pada pengujian yang dilakukan pada mesin D didapatkan nilai OEE sebesar $0.48 \%$. Pengujian Repeatability sistem.

\section{IV.PENUTUP}

Production Monitoring System berbasis IoT adalah sistem yang efektif dan efisien untuk digunakan pada sebuah industri. Berdasarkan pengujian yang telah dilakukan terhadap sistem kendali robot, dapat ditarik beberapa kesimpulan sebagai berikut:

1. Proses monitoring produksi sistem bekerja secara akurat pada perhitungan actual produksi mesin dengan respon data $\pm 2 \mathrm{~s}$ dengan akurasi $0.2 \%$.Perhitungan nilai efisiensi mesin meliputi Availability, Performance, Quality, dan OEE bekerja secara akurat dan handal dengan akurasi sebesar $0.2 \%$ dan error presisi sebesar $1 \%$.

2. Sistem PMS mampu bekerja secara reliable dan user friendly sesuai hasil kuesioner yang dilakukan.

3. Rata-rata waktu respon yang dibutuhkan untuk mengeksekusi perintah manual yang diberikan pada koneksi HSDPA adalah 2.51 detik, sedangkan pada koneksi LTE adalah 2.04 detik.

4. Kecepatan untuk proses perhitungan dan pembacaan semua nilai mesin yang ada pada sistem dengan konektivitas $L T E$ sekitar \pm 2 s.

5. Sistem monitoring yang telah dibuat berhasil menjawab dan mengatasi masalah pada penelitian sebelumnya mengenai perhitungan nilai efisiensi mesin, respon waktu yang lebih cepat, user friendly interface, akurasi data yang handal, dan sistem PMS yang mobile dan reliable.

\section{UCAPAN TERIMAKASIH}

Kami mengucapkan terima kasih yang sebesarbesarnya kepada pihak Polman Bandung yang telah memberikan bantuan berupa fasilitas dan dana penelitian juga rekan dosen yang telah memberikan sumbangsih pemikiran dan tenaganya sehingga penelitian ini dapat selesai tepat waktu.

\section{DAFTAR PUSTAKA}

[1] Bhushan.Golechha, Prashant S. Kulkarni. Design, Analysis And Optimization Of 10 Ton Pneumatic Press Machine : A Review. IJARIIE-ISSN(O)-2395-4396. Vol-3 Issue-1 2017 page 414-419

[2] Wang, Y, Yin, Y, \& Jiang, Y. etc. Chinese real-time dynamic monitoring of system development and implementation of the Strategy[J]. 2005, 29(11): 44-48.I.S

[3] Tang, B, Zeng, N, \& Zheng, X. etc. Web-based Embedded System Design and Implementation of remote monitoring and control [J]. 2004, 43(5): 632-635.

[4] Cowling, P. Johansson, M. Using real time information for effective dynamic scheduling. European Journal of Operational Research. 2002, 139, 230-244.

[5] Saenz de Ugarte, B. Ariba, A. and Pellerin, R. Manufacturing execution system - a literature review. Production Planning \& Control. 2009, 20, 6, 525-539.

[6] Snatkin, A; Karjust, K. Eiskop, T. Real Time Production Monitoring system in SME. $8^{\text {th }}$ International DAAAM Baltic Conference "INDUSTRIAL ENGINEERING" 19-21 April 2012, Tallinn, Estonia

[7] S. K. SUBRAMANIAM 1, S. H. HUSIN 2, Y. YUSOP 3, A. H. HAMIDON 4. Machine efficiency and man power utilization on production lines. Proceedings of the 8th WSEAS Int. Conf. on ELECTRONICS, HARDWARE, WIRELESS and OPTICAL COMMUNICATIONS. 29 May 2014. Pages 70-75.

[8] Meyer, H. Fuchs, F. Thiel, K. Manufacturing execution systems: optimal design, planning, and deployment. McGraw Hill, New York, 2009.

[9] Prasetyo Hoedi, Sugiarto Y and Cucuk Nur Rosyidi. Design of An Automatic Production Monitoring System on Job Shop Manufacturing.2018, doi: 10.1063/1.5024080

[10] S. Sukaridhoto, Bermain Dengan Internet of Things dan Big Data, Surabaya: Politeknik Elektronika Negeri Surabaya, 2016.

[11] F. Mattern, C. Floerkemerier, From the Internet of Computers to the Internet of Things, Informatik-Spektrum, Vol. 33, No. 2, 2010, pp.107-121.

[12] Meyer, H. Fuchs, F. Thiel, K. Manufacturing execution systems: optimal design, planning, and deployment. McGraw Hill, New York, 2009.

[13] Siva Kumar a/l Subramaniam, Siti Huzaimah binti Husin, Yusmarnita binti Yusop and Abdul Hamid bin Hamidon, "Real Time Production Performance Monitoring System a Production Aid for all Industries". The 6th WSEAS International Conference on Circuits, Systems, Electronics, Control \& Signal Processing (CSECS 07) World Scientificand Engineering Academy and Society, 29-31 December 2007, Page(s):181-184.

[14] Baudoux Nicolas and Bauwin Lucie. Real-Time database: Firebase INFO-H-415:Advanced database. Université Libre de Bruxelles. Academic year 2017-2018.

[15] H. Kagermann, W. Wahlster, J. Helbig, Recommendations for implementing the strategic initiative Industrie 4.0 - Final report of the Industrie 4.0 Working Group. Berlin, Communication Promoters Group of the Industry-Science Research Alliance, 2012.

[16] Lei Wu, Jie Hu. Design and Implementation of Production Environment Monitoring System Based on GPRS-Internet. Fourth International Conference on Genetic and Evolutionary Computing. 2010. Pages 818-821

[17] Guo-dong Zhu, Chang-sheng Ai Li-jun Qian. "On-line Monitoring and Control System of Steel Ball Production Based on WiFi Internet of Things". International Conference on Wireless Communication and Sensor Network. 2014. Page(s):127-131.

[18] Abdelhameed, Magdy. 2014. VDI 2206. Cairo: Ain Shams University. 